\title{
ODBORI DOBROČINSTVA U JAPANU, EGIPTU I FRANCUSKOJ U PRVOM SVETSKOM RATU
}

\author{
Milena Žikić \\ Univerzitet Privredna akademija u Novom Sadu, Farmaceutski fakultet
}

U radu su prikazana tri Odbora, formirana na teritoriji Dalekog i Bliskog istoka i zapadne Evrope, za pomoć Srbiji u vreme Velikog rata. Na osnovu predočenih podataka može se uočiti učešće žena u organizovanju pomoći, za srpske vojnike, zatvorenike i ratnu siročad, u novcu i sanitetskom materijalu.

Ključne reči: Odbori dobročinstva, Egipat, Japan, Avr

Drvi svetski rat predstavlja najveći oružani sukob na početku 20. veka. U vrtlogu interesnih ciljeva velikih sila Srbija je bila izložena napadu Austrougarske, Nemačke i Bugarske (Centralne sile). Veliku pomoć Srbiji - članici Antante su pružile sve sile Saveznice. Ostrvska država Japan, na početku Prvog svetskog rata, otpočela je prikupljanje priloga za ranjene i bolesne srpske vojnike u sanitetskom materijalu i novcu. Egipat, država u dolinama Delte i Nila, je formirao Odbor za prikupljanje pomoći za decu srpskih ratnika. U Francuskom gradu Avru osnovano je Društvo za slanje pomoći srpskim zarobljenicima. Potrebno je naglasiti da su u svim Odborima žene imale veliku ulogu u organizovanju, prikupljanju priloga i distribuciji pošiljaka. Srpska vlada je u znak zahvalnosti za pruženu pomoć sve zaslužne odlikovala.

\section{Odbor za prikupljanje priloga u sanitetskom materijalu i novcu u Japanu}

Na početku Prvog svetskog rata (1914), na Bliskom istoku, u državi Japan je formiran Odbor za prikupljanje priloga u sanitetskom materijalu i novcu, za ranjene $i$ bolesne srpske vojnike. Odbor je organizovan u Tokiju, zahvaljujući profesoru Dušanu Todoroviću i supruzi ambasadora u Japanu, markizi Gvičijali. ${ }^{1}$

Odbor je bio sastavljen od žena, a jedna od njih bila je supruga profesora Todorovića, Katarina Šlezinger - Todorović. Prilozi su prikupljani za Srpsko društvo Crvenog krsta. U toku svog rada Odbor je poslao sanitetski materijal u vrednosti od 80.000 jena i nekoliko hiljada u gotovom novcu. U skladu sa načinjenim angažmanom, gospodin Todorović je oktobra 1916. godine predložio najzaslužnije za odlikovanje Ordenom Svetog Save različitih stepena. Prva na spisku bila je kći ruskog ambasadora u Tokiju, Evgenija

${ }^{1}$ AS, MID-PO, rolna 520, dokument V/741. 
Nikolajevna Maljevskaja - Maljević (Evgenie Malevshy - Malevitch), a zatim predsednica ženskog odeljenja Japanskog Crvenog krsta, markiza Ej Nabešima (La Marquise Nabeshima) i supruga profesora Todorovića, Katarina Šlezinger - Todorović, sve tri predložene za Orden Svetog Save petog reda. ${ }^{2}$

Za Orden Svetog Save četvrtog reda predložene su: grofica Tej Ogasavara (La Contesse Ogasavara), supruga vicepredsednika, vikontesa Cidzu Hanabusa (La Visontesse Hanabusa), supruga predsednika, baronesa Kuva Ozava (La Baronne Osava), supruga vicepredsednika i baronesa Marija Ito (La Baronne Ito), supruga admirala Itoa. ${ }^{3}$ Odlukom gospodina Pašića sva predložena lica za odlikovanje iz Odbora za prikupljanje priloga za Srpski Crveni krst u Japanu, nagrađena su Ordenom Svetog Save.

\section{Odbor za prikupljanje pomoći za decu srpskih ratnika - Egipat}

Na Dalekom istoku, u Egiptu, je za vreme Prvog svetskog rata obrazovan Odbor za prikupljanje pomoći za decu srpskih ratnika. Inicijator pomenutog odbora bila je irska bolničarka Silvija Makilkadi, koja je radila u Srbiji do okupacije. Nakon okupacije radila je na Krfu, kao i na ostrvu Vidu gde je pridodata francuskoj misiji. Međutim, pošto nije mogla da ostane pod upravom vojnog Francuskog sanitetskog odeljenja šest meseci, otputovala je za Egipat. Tamo se zainteresovala za prikupljanje novca za srpsku ratnu siročad. U pismu upućenom ministru prosvete Ljubomiru Davidoviću, zapisala je: „Leži mi jako na srcu interesi siročadi srpske i mi koji smo ovde u Egiptu pokušaćemo da prikupimo što god novca za praktično vaspitanje izvesnog broja dece. [...] Mnogi od mojih prijatelja, kako u Americi tako i u Engleskoj i Irskoj, interesuju se za vaspitna pitanja i uverena sam da bi pomogli novčano ovu ideju. "

Ova preduzimljiva žena je odmah sprovela i konkretne korake, uputivši stanovnicima Egipta apel za izgradnju pansionata: „Traži se od Vas da priložite prema vašim sredstvima što više možete, tako da u budućnosti ovaj pansionat bude živi spomen onog što je Egipat učinio da pomogne našeg saveznika hrabrog. [...] Naša je zamisao da stvorimo taj pansionat i da ga po završetku rata izdržavamo za nekoliko godina, tako da naši hrabri srpski saveznici ne moraju o tome da se brinu. Traži se od Vas da priložite prema vašim sredstvima što više možete, tako da u budućnosti ovaj pansionat bude živi spomen onog što je Egipat učinio da pomogne našeg saveznika hrabrog. "6 ${ }^{6}$ Cilj izgradnje pansionata je bio da se u njemu deca poginulih ratnika vaspitavaju i za budućnost od njih stvore dobri građani, a o preduzetim koracima bolničarka Silvija Makilkadi je obavestila i ministra prosvete Ljubomira Davidovića i zatražila da, ukoliko je u prilici, i sam lično poseti

\footnotetext{
${ }^{2}$ AS, MID-PO, rolna 520, dokument V/741.

${ }^{3} \mathrm{Na}$ spisku se nalaze i četiri gospodina. Sekretari Crvenog krsta Japana, Entaro Ješijasu i Madžuziro Gato predloženi su za Orden Svetog Save petog reda, a Džujanosuke Hipuči, profesor centralnog Kadetskog korpusa u Tokiju i Teruzo Masaki, glavni direktor Japanskog prekookeanskog padobranskog društva za Orden Svetog Save četvrtog reda. (AS, MID, PO, rolna 520, dokument V/741)

${ }^{4}$ AS, MID, PO, rolna 520, dokument V/743.

${ }^{5}$ AS, MPs, f. 10, r. 45, 1917.

${ }^{6}$ AS, MPs, f. 10, r. 45, 1917.
} 
Egipat, pošalje izaslanika ili nju ovlasti za prikupljanje novca. ${ }^{7}$ Nakon prijema pisma izaslanik ministra prosvete je zahvalio na ideji za pomoć srpskoj siročadi. „Vaše pismo, kojim izveštavate da ste u Egiptu obrazovali Odbor za prikupljanje pomoći za decu srpskih ratnika, primio je g. Ministar Prosvete - Davidović i uoči svoga polaska u Francusku, kuda je otputovao da obiđe srpsku decu po francuskim školama i sa kojega će se puta vratiti tek krajem ovog meseca, g. Ministar mi je naredio i ovlastio da Vam izjavim njegovu duboku zahvalnost na plemenitom koraku kojim nameravate, pored dosadašnjeg truda na pomoći srpskom narodu, uložiti i za srpsku siročad. On Vas, uz svoju zahvalnost, moli da i dalje produžite rad na tome plemenitom poslu. Na žalost $\mathrm{g}$. Ministru zbog današnjih prilika, nije omogućeno da dođe lično u Egipat, niti da pošalje svoga izaslanika."

$\mathrm{Na}$ osnovu prepiske između irske bolničarke Silvije Makilkadi i zastupnika ministra prosvete može se zaključiti da je srpska država dobijala veliku pomoć od države saveznice - Egipta, kao i da je Odbor za pružanje pomoći deci srpskih ratnika bio od velikog značaja.

\section{Društvo za slanje pomoći srpskim zarobljenicima u Avru}

Novembra 1916. godine u gradu Avru (Francuska) humani ljudi osnovali su Društvo za slanje pomoći srpskim zarobljenicima, na čijem čelu se nalazila gospođa Karla Kronhajmer. Zarobljenici su od Društva dobijali pakete sa rubljem, obućom i odećom, ali i hranom. Početna dinamika isporuke u toku prvih pet meseci bila je takva da je svaki petnaesti zarobljenik primao paket, da bi već nakon prve pošiljke (novembar 1916) Društvo dobilo preporuke za sadržinu paketa i njihov veći broj. Sve je to uticalo da broj donatora poraste, a samim tim se i broj paketa sa 15 povećao na 250.

Gospođa Kronhajmer uspostavila je vezu sa Crvenim krstom Ženeve, kao i sa Srpskim Cvenim krstom na Krfu od koga je i dobila odobrenje za upotrebu njihovog pečata. Da bi prikupila neophodna sredstva za slanje paketa, predsednica je putem novina u Avru uputila apel svim dobrim ljudima za priloge i pomoć srpskim zarobljenicima. Za pomoć se obratila i svojim mnogobrojnim imućnim poznanicima i prijateljima. Tokom 1917. godine, organizovala je i priredila nekoliko koncerata, fudbalskih utakmica i gimnastičkih igara, sakupivši veliku svotu novca u vidu donacija. Veliku pomoć u radu Društva pružile su joj i Francuskinje angažovane na pripremi i slanju paketa, kao i Srpkinja Milanka Nusbaum, udata za Švajcarca dr Nusbauma, velikog dobrotvora pomenutog društva. Zajedno su bili zaduženi za prevod pisama i karata srpskih zarobljenika upućenih Društvu, u kojima su bila popisana neophodna sredstva. Do prve polovine 1918. godine poslato je 10.500 paketa. Društvo je funkcionisalo zahvaljujući dobrom radu blagajnice gđe Povileviteg (Rowilewiteg), kao i gospođa Kaspentije (Cazpentiers), Buznije (Buznier), De la Blanšete (de la Blanchetais) i Kozbon (Cozbon). Sve pomenute gospođe su odlikovane Krstom milosrđa, a gđa i gospodin Kronhajmer, koji su finansijski potpomogli rad Društva, Ordenom Svetog Save četvrtog reda. ${ }^{9}$

\footnotetext{
${ }^{7}$ AS, MPs, f. 10, r. 45, 1917.

${ }^{8}$ AS, MPs, f. 10, r. 45, 1917.

${ }^{9}$ VA, P-5, K. 102, F. 5, D. 25.
} 
Prijateljska pomoć Kraljevini Srbiji, kao i podrška, podstrek i potpora u danima odluke i nedoumice, nije izostajala ni u toku Velikog rata. Srbija je bila pomognuta od strane svojih prijatelja koji su živeli i u zemljama istočnog dela Mediterana i u istočnoazijskim zemljama uz Tihi okean. Geografska udaljenost nikoga nije sprečavala da pomogne ugroženom, napaćenom i okupiranom narodu Srbije. Odbori za pomoć su omogućili opstanak srpskog naroda uz pomoć novca ili sanitetskog materijala. Srpska siročad, zarobljenici i vojnici su zahvaljujući Odborima, širom sveta i u najtežim trenucima, bili pomognuti.

\section{Izvori}

[1] Arhiv Srbije Beograd (AS)

- Ministarstvo inostranih dela - Beograd (1838-1920) - političko odeljenje (MID-PO)

- Ministarstvo prosvete u izbeglištvu - Krf (1916-1924) (MPs)

[2] Vojni arhiv Beograd (VA)

- Fond Vojska Kneževine/Kraljevine Srbije, 1847-1920.

- Popisnik br. 5 - Ratna arhiva Ministarstva vojnog, sa odeljenjima i ustanovama, od 1914. do 1923. godine. 